\title{
РОЗВИТОК ІНТЕЛЕКТУАЛЬНОЇ КОМУНІКАЦІЇ В УЧНІВСЬКОЇ ТА СТУДЕНТСЬКОЇ МОЛОДІ ХХІ СТОЛІТТЯ
}

\author{
Ф. Я. Майнаєв \\ здобувач кафедри загальної педагогіки та педагогіки вищої школи ХНПУ імені Г.С. Сковороди \\ учитель історії, 33СО І-ІІІ ступенів №13 військово-цивільної адміністрації міста Торецьк Донецької обл.
}

\section{О. І.Майнаєва}

учитель української мови та літератури,

Опорний заклад «Торецька ЗОШ І-ІІІ ступенів №6» військово-цивільної адміністрації міста Торецьк Донецької обл.

Успішність випускника закладу загальної середньої освіти (З3СО), закладу вищої освіти (ЗВО) залежить від його здатності до комунікації. «Заберіть у мене все, чим я володію, але залиште мені мою мову, і скоро я знайду все, що мав», — цей афоризм Даніеля Уебстера, американського політика XIX століття, не втратив своєї актуальності в нашому цифровому XXI столітті.

Стрімкий розвиток інформаційно-комунікаційних технологій (IКТ), розширив способи й засоби комунікації. Публічні особи й пересічні громадяни для доведення власної думки вдаються до відеобатлів, поширюють меми в мережі Інтернет, висловлюють свою позицію стосовно події (культурної, політичної, соціальної) через малюнок, фото, плакат на сторінці у Facebook, Instagram чи Twitter. Будь-яка інтернет-публікація (відео, текст, графіка) може спричинити спонтанну дискусію, учасники якої нерідко Argumentum ad Hominem (спростовують аргумент, посилаючись на характер, мотив віртуального співрозмовника), із метою отримання перемоги над опонентом намагаються принизити його, уживають образливі вирази, ненормативну лексику. На жаль, у реальному житті ми також можемо стати свідками невдалого завершення комунікації (взаємообрази, бійки). Про це повідомляють заголовки газет і журналів, телевізійні новини, інтернет-публікації. Тому формування, а відтак розвиток інтелектуальної комунікації є одним із нагальних питань, яке має вирішувати освітянська спільнота. Розв'язанню цього важливого завдання можуть сприяти суспільно-гуманітарні науки, що мають потужний розвивальний і виховний потенціал.

Роль суспільних і гуманітарних наук у становленні особистості, формуванні й розвитку в неї важливих життєвих компетенцій розглядали такі зарубіжні науковці, як: Н. Анстед, Е. Гібсон, М. Епштейн, К. Райфф, С. Стюарт, Е. Уотсон, Н. Фрай, С. Фуллер, Е. Хазелкорн, Дж. Харфем.

Так, С. Фуллер [9], американський філософ-соціолог у галузі досліджень науки й техніки, зазначає, що люди відчувають потребу в гуманітарних науках, якщо самі віддані ідеї людяності. Якщо гуманітарні науки застарівають, людство втрачає свою значущість. Дослідник, аналізуючи їх вплив на університетську освіту, доходить висновку, що саме гуманітарні науки забезпечують навички, необхідні для сучасних досліджень.

Інший філософ М. Епштейн уважає, що найзахопливіші досягнення сучасної цивілізації, які найбільше впливають на людське життя, із самого початку несуть у собі яку-небудь гуманітарну ідею: естетичну, етичну, психологічну [3, с.18].

Важливість суспільних і гуманітарних наук у професійній освіті, підтверджують результати дослідження (2014), проведеного Асоціацією американських коледжів й університетів. Воно показало, що підприємці й роботодавці наполегливо прагнуть винаймати випускників, які володіють здатністю критично мислити, комунікувати й розв'язувати складні завдання. Це є тими навичками, як уважає професор історії Е. Уотсон, що отримуються саме в процесі навчання суспільних і гуманітарних наук [10].

Успішна журналістка й водночас історик А. Руджер [8], розмірковуючи над корисністю чи марністю гуманітарних наук для професійного зростання, посилається на дослідження, проведене компанією Glassdoor (2019), яке виявило, що вісім із десяти найкращих робочих місць у Великобританії вимагали від працівників навичок спілкування й володіння емоційним інтелектом. Водночас перевага гуманітарної освіти полягає в тому, що воно робить акцент на навчанні студентів мислити, критикувати, переконувати.

Н. Анстед [7], учитель, переможець престижного конкурсу Milken Educator Award, переконаний, що вивчення гуманітарних наук допомагатиме учням у прийнятті рішень, заснованих на цінностях. Вивчаючи історію, літературу, вони навчаються академічній дискусії: аналізують, ретельно добирають аргументи.

Схожі думки знаходимо в працях українських дослідників (Ю. Балуєва, Г. Клочек, О. Кравченко-Дзондза, О. Пометун, С. Ралькіна, А. Ремньова).

Так, А. Ремньова [5], досліджуючи проблему виховання толерантності в учнів 5-7 класів звертає увагу на виховний потенціал уроків історії, який допомагає формувати навички творчого опрацювання інформації та критичного мислення, що сприяє формуванню власної думки шляхом зіставлення різних фактів і позицій, взаємоповаги, терпимості до чужих думок і поглядів. 
Г. Клочек [1], розглядаючи стратегію та тактику реформування шкільної освіти, наголошує на ролі української літератури в забезпеченні формування таких ключових компетентностей здобувача загальної середньої освіти, як «Спілкування державною (і рідною у разі відмінності) мовами», «Загальнокультурна грамотність». Науковець пише: «Потреба в зубрінні, у запам'ятовуванні різної інформації, яку вимагали досі чинні програми, залишилася позаду як пройдений етап, бо в сучасних умовах будь-яку інформацію за лічені секунди легко здобути з Інтернету. Натомість важливо добитися, щоб школа озброювала учнів тими знаннями і практичними вміннями, які будуть потрібні їм у XXI ст.».

О. Кравченко-Дзондза [2], розмірковуючи над завданнями забезпечення вищої освіти, уважає найважливішими 3 них загальний розвиток студентів, удосконалення їх комунікативної компетентності. На думку дослідниці, досягненню цьому сприяють суспільні й гуманітарні науки (у контексті ії дослідження — культурологія).

Зважаючи на актуальність порушеної проблеми, розглянемо розвиток інтелектуальної комунікації учнівської та студентської молоді засобами суспільних і гуманітарних дисциплін (українська література, історія).

Відповідно до психолого-педагогічного словника, комунікація є змістовною сутністю соціальної взаємодії, що характеризує структуру міжособистісних і ділових зв'язків між людьми, особливості обміну інформацією в людському спілкуванні [6, с.193].

У науковій літературі зустрічаються й інші визначення цього поняття: процес передавання інформації за допомогою знакових систем (Р. Якобсон); цілеспрямований процес, одним із засобів якого є мовлення, а знаковою цілісною формою організації текст (О. Селіванова); вплив одного суб'єкта на іншого як об'єкт власної активності за допомогою передавання знань, відомостей, уявлень (І. Омельченко); практичне вміння перекладати текст із мови «я» на мову твого «ти» (Ю. Лотман); процес активного та пришвидшеного обміну інформацією (Г. Онуфрієнко, А. Черневич).

У результаті аналітичної обробки визначень поняття «комунікація» ми виокремили такі основні його ознаки: взаємодія, інформація, обмін інформацією. Відповідно якість комунікації визначається якістю взаємодії, здійсненням обміну інформацією та якістю самої інформації. Якщо інформаційні повідомлення характеризуються глибиною суджень, які є результатом пізнання й осмислення фактів, подій, явищ, процесів, здатністю адекватно реагувати на повідомлення, готовністю до прийняття спільного рішення щодо предмета обговорення (дискусіі), то таку комунікацію можна вважати інтелектуальною.

Термін «інтелектуальна комунікація» у Державному стандарті базової середньої освіти, Концепції Нової української школи не вживається. Натомість у Стандарті вищої освіти України, зокрема галузі знань «03 Гуманітарні науки» спеціальностей «032 Історія та археологія», «033 Філософія» це поняття є присутнім. Чи означає це, що в шкільній освіті немає місця інтелектуальній комунікації? Для того щоб відповісти на це запитання, проаналізуємо зміст інтелектуальної комунікації відповідно до змісту ключових компетентностей, які визначені в навчальних програмах для 33СО з української літератури, історії.

У Стандарті вищої освіти спеціальностей «032 Історія та археологія», «033 Філософія» визначено такий зміст інтелектуальної комунікації:

- Увага й толерантність до іншої (й інакшої) думки, здатність аналізувати їі зміст і структуру в процесі спілкування й адекватно на неї реагувати.

- Здатність брати участь в інтелектуальних дискусіях, використовувати ввічливі форми звернення до опонента, концентруватися на значущих складових судження, не переходячи на особистості.

- Навички публічного мовлення, здатність ясно та виразно висловлюватися в процесі комунікації.

- Навички роботи в групі, розподіл функцій в колективній роботі.

- Відкритість, здатність сприймати та враховувати зауваження, оптимізувати власну позицію в процесі обговорення, налаштованість на діалог, залучення у власні міркування висловлених слушних ідей.

- Навички використання інформаційних і комунікаційних технологій.

На основі аналізу програм для 33СО з української літератури, історії України, всесвітньої історії (5-9, 10-11 класи) ми виявили, що інтелектуальну комунікацію як компетентність окремо в цих документах не винесено. Проте компоненти змісту інтелектуальної комунікації є присутніми в змісті таких ключових компетентностей випускника 33СО, як спілкування державною (і рідною, у разі відмінності) мовою, математична компетентність, інформаційно-цифрова компетентність, уміння вчитися впродовж життя, ініціативність і підприємливість, соціальна та громадянська компетентності. Так, до змісту такої ключової компетентності, як спілкування державною (і рідною, у разі відмінності) мовою входить три навички із шести, що характеризують інтелектуальну комунікацію. Результати здійсненого аналізу представлено в наведеній нижче таблиці. 
Відповідність компонентів змісту інтелектуальної комунікації змісту ключових компетентностей випускника 33СО

\begin{tabular}{|c|c|c|}
\hline $\begin{array}{l}\text { Компоненти змісту } \\
\text { інтелектуальної } \\
\text { комунікації }\end{array}$ & $\begin{array}{l}\text { Історія України. } \\
\text { Всесвітня історія }\end{array}$ & Українська література \\
\hline $\begin{array}{l}\text { Увага, толерантність до іншої } \\
\text { (й інакшої) думки, здатність } \\
\text { аналізувати її зміст та } \\
\text { структуру }\end{array}$ & $\begin{array}{l}\text { Спілкування державною мовою (розуміти } \\
\text { цінності кожної мови; толерантно ставитися до } \\
\text { висловлювань інших людей) }\end{array}$ & $\begin{array}{l}\text { Соціальна та громадянська } \\
\text { компетентності (поважати різні } \\
\text { погляди, ідеї та вірування; } \\
\text { утверджувати права кожного на } \\
\text { власну думку) }\end{array}$ \\
\hline $\begin{array}{l}\text { Здатність брати участь в } \\
\text { інтелектуальних дискусіях }\end{array}$ & $\begin{array}{l}\text { Спілкування державною мовою (вести } \\
\text { аргументовану дискусію на відповідну тематику) }\end{array}$ & $\begin{array}{l}\text { Спілкування державною мовою } \\
\text { (уміти толерантно дискутувати, } \\
\text { відстоювати власну думку) }\end{array}$ \\
\hline $\begin{array}{l}\text { Навички публічного } \\
\text { мовлення, здатність ясно, } \\
\text { виразно висловлюватися в } \\
\text { процесі комунікації }\end{array}$ & $\begin{array}{l}\text { Спілкування державною мовою (доступно } \\
\text { та переконливо висловлювати думки, } \\
\text { використовувати виражальні можливості мови для } \\
\text { опису подій минулого й сучасності та реагувати } \\
\text { мовними засобами на соціальні й культурні явища) } \\
\text { Математична компетентність (оперувати } \\
\text { цифровими даними, математичними поняттями } \\
\text { для пізнання та пояснення минулого й сучасних } \\
\text { суспільних подій, явищ,процесів; будувати логічні } \\
\text { ланцюжки подій, вчинків; використовувати } \\
\text { статистичні матеріали у вивченні історії) }\end{array}$ & $\begin{array}{l}\text { Спілкування державною мовою } \\
\text { (послуговуватися державною } \\
\text { мовою в різноманітних життєвих } \\
\text { ситуаціях) } \\
\text { Математична компетентність } \\
\text { (виокремлювати головну } \\
\text { й другорядну інформацію; } \\
\text { установлювати причинно- } \\
\text { наслідкові зв’язки) }\end{array}$ \\
\hline $\begin{array}{l}\text { Навички роботи в групі, } \\
\text { розподіл функцій у } \\
\text { колективній роботі }\end{array}$ & $\begin{array}{l}\text { Ініціативність та підприємливість (працювати } \\
\text { самостійно, у групі; планувати, організовувати, } \\
\text { реалізовувати індивідуальні,командні проекти) }\end{array}$ & $\begin{array}{l}\text { Уміння вчитися впродовж життя } \\
\text { (працювати в парі, групі) }\end{array}$ \\
\hline $\begin{array}{l}\text { Відкритість, здатність } \\
\text { сприймати, враховувати } \\
\text { зауваження, оптимізувати } \\
\text { власну позицію в процесі } \\
\text { обговорення }\end{array}$ & $\begin{array}{l}\text { Уміння вчитися впродовж життя (відкритість } \\
\text { до сталого самонавчання, бажання ділитися } \\
\text { знаннями з іншими) }\end{array}$ & $\begin{array}{l}\text { Ініціативність, підприємливість } \\
\text { (презентувати власні ідеї та } \\
\text { ініціативи чітко, грамотно, } \\
\text { використовуючи доцільні мовні } \\
\text { засоби) }\end{array}$ \\
\hline Навички використання IКТ & $\begin{array}{l}\text { Інформаційно-цифрова компетентність } \\
\text { (використання цифрових технологій для пошуку } \\
\text { потрібної історичної та соціальної інформації) }\end{array}$ & $\begin{array}{l}\text { Інформаційно-цифрова } \\
\text { компетентність (робота в } \\
\text { різних пошукових системах для } \\
\text { отримання потрібної інформації) }\end{array}$ \\
\hline
\end{tabular}

Отже, 3ЗСО є майданчиком розвитку окремих компонентів інтелектуальної комунікації. Їх основою $€$ вміння ставити запитання та вміння слухати.

Уміння ставити запитання $є$ показником уміння будувати зв'язки між власними знаннями про предмет обговорення та почутою від інших учасників комунікації новою інформацією. Опишемо завдання, які в ігровому форматі навчають учнів ставити запитання.

«Крокодил». Відома й досить поширена гра, суть якої - відгадати задумане слово — літературний персонаж, історичну постать, назву поняття (у межах теми, яка вивчається). Існує два варіанти гри. За першим варіантом слово задумує клас, відгадує один учень. За другим варіантом слово задумує один учень, відгадує клас. Той, хто відгадує, може поставити запитання, яке передбачає відповідь або «Так», або «Ні». Вправа «Крокодил» актуалізує опорні знання (учневі потрібно пригадати характерні риси персонажа (постаті) чи ознаки поняття, дібрати відповідні мовні засоби для формування запитання); сприяє розвитку вміння ставити запитання закритого типу.

«Сім запитань». Учням необхідно побудувати одне речення за змістом тексту (відео, картина, малюнок), яке б містило відповіді одночасно на сім запитань :хто? що? де? коли? чому? для чого? як? Отже, під час виконання завдання учні здійснюють операцію аналізу, відшукуючи сім ключових слів, і синтезу, оформлюючи потім ці ключові слова в речення, що сприяє стимулюванню мислення, а також навчає учнів ставити відкриті запитання.

Уміння слухати $є$ не лише ознакою таких особистісних якостей, як уважність, зосередженість, але й показником глибини розуміння інформаційного повідомлення, його прямого та прихованого змісту. Опишемо вправу, яка сприяє розвитку вміння слухати.

«Коло думок». Учні стають у коло. Учитель кидає м'яку іграшку (м'ячик) учневі зі словами «Я думаю, що..., а ти?» Учень передає її наступному, висуваючи свою версію пояснення. Перехід до наступного питання відбувається тоді, коли попереднє є вичерпаним. Сигналом для нього є слова «Я погоджуюся з вашими думками». 
Наведемо фрагмент уроку української літератури в 6 класі. Вправа «Коло думок» використовувалася для формування розуміння глибини байки Л. Глібова «Щука» та розвитку вміння слухати. Запитання для обговорення подавалося у вигляді стверджувального речення, яке необхідно було або довести, або спростувати:

- Я думаю, що за стряпчого була приставлена Лисичка, бо вона дуже розумна. А ти як думаєш?

- Я думаю, що судді погодилися з пропозицією Лисички, бо вона 3 ними ділилася пригощаннями Щуки. А ти як думаєш?

- Я думаю, що скаргу на Щуку в суд подала сама ж Лисичка, щоб ще більше отримати з Щуки. А ти як думаєш?

- Я думаю, що Щука більше не буде щовечора посилати Лисичці то «щупачка, то сотеньку карасиків живеньких або линів гарненьких». А ти? [3]

Виконуючи завдання, учні висувають власне розуміння змісту байки, пояснюють вчинки ії персонажів, що може різнитися від відповіді інших учасників «Кола думок». I це при побудові власного судження необхідно враховувати. Отже, під час виконання цього завдання реалізується така виховна ціль, як толерантне ставлення до іншої думки.

Ми уважаємо, що думку необхідно виховувати: вона є результатом уявлення особистості про моральноетичні цінності. Але думку не можна нав'язувати. Вона має бути вільною, незалежною від стереотипів, поглядів авторитетів, водночас будуватися не на емоціях, а на знаннях, при цьому не на поверховому знанні предмета обговорення (хто? де? коли?), а глибокому розумінні його суті (чому?). Такі думки породжують судження, що є ознакою інтелектуальної дискусії.

Педагогічний досвід свідчить, що учням цікаво спостерігати за дискусією, але сама участь у ній є для них складним завданням. Найчастіше це пов'язане з тим, що учні бояться критики однокласників, помилкових міркувань, остерігаються, що ровесники не зрозуміють їх. Подоланню цього бар'єра сприятиме виконання вправи «Територія вільних думок».

На відміну від вправ «Крокодил», «Сім запитань», «Коло думок», робота над якими здійснюється на уроці, до «Території вільних думок» учні залучаються у вільний час (до початку уроків, на перерві, після уроків). Тому виконання завдання в ній потребує наявності в учнів мотивації до цього, стимулювання їх до позаурочної навчальної діяльності.

У класі вивішується плакат, на якому зображені хмарки (кола) за кількістю учнів у класі. Угорі пишеться правило «Території вільних думок» - «Кожен має право на свою думку» та питання для обговорення. Учням пропонується протягом тижня написати своє судження (відповідь) із 2-3 речень. Не обов’ язково підписуватися. Але не можна редагувати чуже судження, виправляти в ньому будь-які помилки.

Так, під час обговорення питання «Чи може спілкування в Інтернеті замінити справжні стосунки?» на «Території вільних думок» з’явилися такі цікаві вислови: «В Інтернеті я справжній, поза Інтернетом граю роль», «В Інтернеті Ромео ніколи б не знайшов свою Джульєтту».

Підсумок роботи - статистичний звіт про результати обговорення (готує один з учнів), перегляд відеоролика, у якому відома людина або герой літературного твору вирішує це саме питання, але без моралізаторства. Висновок учень має зробити сам.

Ще одним способом формування інтелектуальної комунікації є залучення учнів до передавання своїх думок засобами IКТ. Прикладом такого завдання є відповідь на запитання «Що таке щастя?» у форматі відеоролика (доступ до роботи учня в QR-коді).

Завершити статтю ми хочемо словами Р. Брингхерста «Найбільша загроза комунікації не відмінності, а одноманітність». Зробіть комунікацію на уроці цікавою - і учні зроблять усе, щоб розвинути в себе здатність до неї.

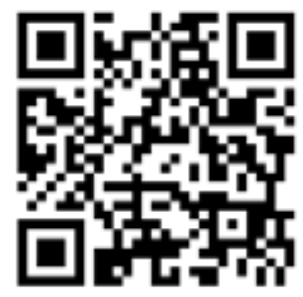

\section{Література}

1. Клочек Г. Літературна освіта в Новій українській школі // Дивослово. 2017. Вип. 1. С.7-11.

2. Кравченко-Дзондза О. Формування комунікативної компетентності студентів у процесі вивчення культурологічних дисциплін. URL : http://dspu.edu.ua/hsci/wp-content/uploads/2017/12/010-34.pdf (дата звернення:16.10.2019).

3. Майнаєва О. I. Розробка уроку // М-вітальня-2018. URL : https:/viddilukrfilolog.wixsite.com/novaschool/toreck (дата звернення: 15.10.2019).

4. Майнаєв Ф. Роль суспільних і гуманітарних наук у формуванні особистості // Пріоритетні напрямки вирішення актуальних проблем виховання і освіти : зб. наук. тез Міжнар. наук.-практ. конф.(Харків, 26-27 липн. 2019 р.). Харків : Східноукраїнська організація «Центр педагогічних досліджень», 2019. С. 17-20.

5. Ремньова А. Г. Виховання толерантності у молодших підлітків у процесі вивчення історії // Методичні рекомендації для вчителів історії, класних керівників та студентів психолого-педагогічних спеціальностей університетів. Київ : НТПУ імені М. П. Драгоманова. 2011. 60 с.

6. Сучасний психолого-педагогічний словник / за заг. ред. О. І. Шапран. Переяслав-Хмельницький : Домбровська Я. М. 2016. C. 193. 
7. Anstead N. Hooking Kids with Humanities. URL : https://is.gd/EYfdWY (дата звернення : 17.10.2019).

8. Ruggeri A. Why 'worthless' humanities degrees may set you for life. URL: https://is.gd/cCEq98 (дата звернення: 20.10.2019).

9. Fuller S. Who Needs the Humanities? // 3 Quarks Daily Science Arts Philosophy Politics Literature. URL: https:// www.3quarksdaily.com/3quarksdaily/2008/07/who-needs-the-h.html (дата звернення: 19.07.2019).

10. Watson E.Studying Always Will Be Important. URL: https://diverseeducation.com/article/63927/ (дата звернення: 12.10.2019). 